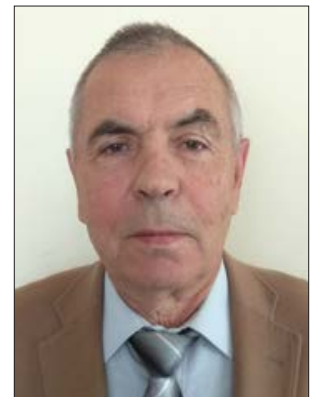

Yuriy

G. Kravchenko

Кравченко

Юрій

Григорович

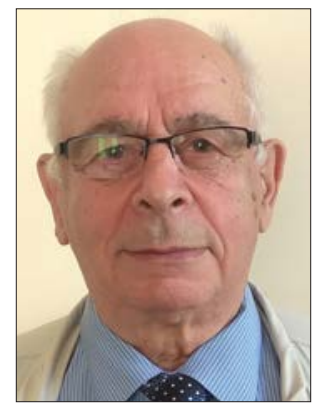

Sergiy

T. Patsera

Пацера

Сергій

Тихонович

УДК 621.922

\title{
THE VALUES OF THE PARAMETRES OF THE ABRASIVE RELIEF OF THE CUTTING SURFACE OF THE ABRASIVE WHEELS
}

\section{ЗНАЧЕННЯ ПАРАМЕТРІВ АБРАЗИВНОГО РЕЛЬЄФУ РІЗАЛЬНОӦ ПОВЕРХНІ АБРАЗИВНИХ КРУГІВ}

DOI https:// doi.org/ 10.15589/smi2019.1(11).4

Yuriy G. Kravchenko

Sergiy T. Patsera

Кравченко Юрій Григорович, канд. техн. наук, доц.

yuriy.kravchenko2019@gmail.com

ORCID: 0000-0003-1306-4161

Пацера Сергій Тихонович, канд. техн. наук, ст. наук. співробітник, sergiy.patsera@ukr.net

ORCID: 0000-0001-9137-3950

Dnipro University of Technology, Dnipro

Національний технічний університет «Дніпровська політехніка», м. Дніпро

Abstract. Purpose is to establish the dependence of the relative bearing length of the profile and the average distance between the grains on the parameters of the characteristics of the abrasive wheel. Methodology. Using the installation of our own design for profile measurements the relief of the cutting surface of polishing wheels in a straight line along one track after dressing with diamond in the frame and after polishing, we studied the influence of the parameters of the characteristics of abrasive wheels (grain, hardness, and structure) on the relative bearing length and the average distance between the protrusions of the profile in depth relief. To achieve this goal, three series of one-factor studies of the pattern of the incisial surface of the circles were carried out. The approximation of the experimental dependences in the logarithmic coordinate system is applied by the methods of determining the exponent for the argument and the selection of the correction coefficient for hardness. Results. The actions of the editing process are described by the dependencies shown in the graphs. As the grain size increases, a substantial decrease in the bearing length and an increase in the distance between the protrusions of the profile occur. Polishing wheels with greater hardness have a greater value of the bearing length and less - the distance between the protrusions of the profile. An increase in the number of the structure of the circles leads to a slight decrease in the bearing length and an increase in the distance between the protrusions of the profile. When polishing wear-proof high-speed steels some increase in the bearing length of the profile is characteristic, and the average distance between the protrusions of the profile remains almost unchanged. The main reason for limiting the durability period of electro corundum circles is the formation of wear pads of grain (for wheels of grain number 60, the width of profile of the wear pad reaches $0.03-0.05 \mathrm{~mm}$, and the total number of blunted grains is about $30 \%$ ). The formula of calculation of the parameters of relief of the incisal surface in the depth of their occurrence based on the values of the concentration grain and the distance between them on the abrasive matrix (the intersection of the abrasive space). Compared with the values of the analytical-probabilistic models of relief, the editing process increases the width of profile of the reference grain and the number of grits per unit of the incisal surface of the circles. Scientific novelty. Determined regularities of the influence of grains, hardness and structure of electro corundum circles on the relative bearing length and distance between the protrusions of the incisal surface of the circles, and the empirical derived formula for their calculation based on the volume concentration of grits and the distance between the grits on the abrasive matrix. Hardness of the circles does the most influence, and structure does the least. Practical significance. The values of the studied parameters of the pattern of the incisal surface of the circles are needed as initial parameters for the calculation of the cut geometry (thickness and length) and the components of the cutting forces when cutting by a single grit.

Key words: abrasive wheels, cutting surface, abrasive relief, grinding, relief parameters, relative support length, distance between grains.

Анотація. Мета встановити залежність відносної опорної довжини профіля і середньої відстані між зернами від параметрів характеристики абразивного круга. Методика. За допомогою установки авторської розробки для профілографування рельєфу різальної поверхні шліфувальних кругів прямолінійно по одній трасі після правки алмазом в оправі і після шліфування проведені дослідження впливу параметрів характеристики абразивних кругів (зернистості, твердості і структури) на відносну опорну довжину 
і середню відстань між виступами профіля по глибині рельєфу. Для досягнення поставленої мети були проведені три серії однофакторних досліджень рельєфу різальної поверхні кругів. Застосована апроксимація експериментальних залежностей в логарифмічній системі координат методами визначення показника ступеня при аргументі і підборі поправочного коефіцієнта на твердість. Результати. Діяння процесу правки описано показаними на графіках залежностями. По мірі збільшення зернистості відбувається суттєве зменшення опорної довжини і збільшення відстані між виступами профіля. Шліфувальні круги з більшою твердістю мають більше значення опорної довжини і меншу відстань між виступами профіля. Збільшення номера структури кругів приводить до незначного зменшення опорної довжини і зростання відстані між виступами профіля. У разі шліфування зносостійких швидкорізальних сталей характерне деяке збільшення опорної довжини профіля, а середня відстань між виступами профіля залишається майже без змін. Головною причиною обмеження періоду стійкості електрокорундових кругів $є$ утворення площадок зносу зерен (для кругів зернистості номер 60 ширина профіля площадки зносу досягає 0,03-0,05 мм, а загальна кількість затуплених зерен становить близько 30\%). Виведена формула розрахунку параметрів рельєфу різальної поверхні по глибині їх залягання на основі значень концентрації зерен і відстані між ними на абразивній матриці (перетину абразивного простору). Порівняно зі значеннями аналітико-ймовірнісної моделі рельєфу процес правки дає збільшення ширини профіля приведеного зерна і кількості зерен на одиниці площі різальної поверхні кругів. Наукова новизна. Встановлені закономірності впливу зернистості, твердості і структури електрокорундових кругів на відносну опорну довжину і відстань між виступами профіля різальної поверхні кругів і виведена емпірична формула їх розрахунку на основі об’ємної концентрації зерен і відстані між зернами на абразивній матриці. Найбільшою мірою впливає твердість кругів, найменшою структура. Практична значимість. Значення досліджених параметрів рельєфу різальної поверхні кругів необхідні як початкові параметри для розрахунку геометрії зрізу (товщини і довжини) і складників сил різання одиничним зерном.

Ключові слова: абразивні круги, різальна поверхня, абразивний рельєф, шліфування, параметри рельєфу, відносна опорна довжина, відстань між зернами.

\section{References}

[1] Popov, S.A., Malevskiy, N.P. (1959). Novyy metod otsyenki rezhushchykh svoistv abrazivnykh instrumentov [A new method for evaluating the cutting properties of abrasive tools]. Moscow: VINITI Publ. [in Russian].

[2] Popov, S.A., Malevskiy, N.P., Tereshchenko, Л.M. (1977). Almazno- abrazivnaia obrabotka metallov i tverdykh splavov [Diamond abrasive processing of metals and hard alloys]. Moscow: Mashynostroenie Publ. [in Russian].

[3] Popov, S.A., Malevskiy, N.P., Buloshnikov, V.S. (1976). Ustroystvo dlia profilografirovaniia relefa rezhushchey poverkhnosti shlifovalnykh krugov na stanke 3A151 [Device for profiling the relief of the cutting surface of grinding wheels on the machine 3A151]. Obrabotka materialov rezaniem. Moscow: VZMI Publ. [in Russian].

[4] Malevskiy, N.P., Buloshnikov, V.S., Popov, S.A. (1980). Stendy i pribory dlia issedovaniia protsessov almazno-abrazivnoy obrabotki materialov [Stands and instruments for researching diamond abrasive materials processing]. Sbornik "Rezanie i instrument". Trudy MVTU. No. 324. Moscow: MVTU Publ. Pp. 80-134. [in Russian].

[5] Popov, S.A., Kravchenko, Yu.G., Zhuchenko, A.V. (1982). Profilografirovanie relyefa rezhushchey poverkhnosti shlifovalnykh krugov [Determination of the profile of the relief of the cutting surface of the grinding wheels]. Sb. "Rezanie i instrument”, No. 27, Kharkov: Vyshcha shkola Publ. Pp. 10-14. [in Russian].

[6] Kravchenko, Yu.G. (1980). Issledovanie protsessa vysokoproizvoditelnogo shlifovaniia slozhnolegirovannykh bystrorezhushchikh staley krugami na keramicheskoy sviazke [Study of the process of high-performance grinding of complex alloyed high-speed steels with ceramic bonded grinding wheels]: Ph.D. dissertation: 05.03.01. Moscow: MVTU Publ. [in Russian].

[7] Murashkin, S.V. (2006). Povyshenie effektivnosti protsessa shlifovaniia za schet pravki shlifovalnykh krugov $\mathrm{s}$ primeneniem ultrazvukovykh kolebaniy [Improving the efficiency of the grinding process by dressing grinding wheels using ultrasonic vibrations]: Abstract Ph.D. dissertation: 05.03.01. Ulianovsk: UlGTU Publ. Retrieved from: http://www.ulstu.ru/main?cmd=file\&object=730 [in Russian].

[8] Malyshev, V.I., Murashkin, S.V, Komlev, R.V. (2010) Formirovanie rabochey poverkhnosti shlifovalnogo kruga pri ultrazvukovoy pravke [The formation of the working surface of the grinding wheel with ultrasonic dressing]. "Vektor nauki TGU”, No. 2(12), Toliatti: TGU Publ. Pp. 40-43. Retrieved from: http://edu.tltsu.ru/sites/sites_content/ site1238/html/media63159/07-Malyshev.pdf [in Russian].

[9] Riabtsev, S.A. (2011). Razrabotka abrazivnogo instrumenta s povyshennoy strukturnostiu i upravliaemoy poristostiu dlia vysokoproizvoditelnogo shlifovaniia fasonnykh poverkhnostey detaley iz trudnoobrabatyvaemykh materialov [Development of an abrasive tool with increased structure and controlled porosity for high-performance grinding of shaped surfaces of parts made of hard-to-work materials]: Doctoral dissertation: 05.02.07. Moskovskiy gosudarstvennyy tekhnologicheskiy universitet “STANKIN”. Moscow: Publ. Retrieved from: https://www.dissercat.com/content/razrabotka-abrazivnogo-instrumenta-s-povyshennoi-strukturnostyu-i-upravlyaemoi-poristostyu-d [in Russian].

[10] Saltykov, S.A. (1970). Stereometricheskaia metallografiia [Stereometric metallography]. Moscow: Metallurgiia Publ. [in Russian]. 
[11] Cherniavskiy, K.S. (1977). Stereologiia v metallovedenii [Stereology in metal science]. Moscow: Metallurgiia Publ. [in Russian].

[12] Kravchenko, Yu.G. (2000). Parametrirovanie abrazivnoy matrizy shlifovalnykh krugov [Parameterization of the abrasive matrix of grinding wheels]. "Rezanie i instrument v tekhnologicheskikh sistemakh", No. 57, pp. 126-130. Kharkov: KhGPU Publ. [in Ukraine].

[13] Kravchenko, Yu.G. (2000). Stroenie iskhodnogo relyefa rezhushchey poverkhnosti shlifovalnykh krugov [The structure of the initial relief of the cutting surface of the grinding wheels]. Zbirnyk naukovykh prats "Vysoki tekhnologii v mashinobuduvanni”, No. 1(3), pp. 154-160. Kharkiv: KhDPU Publ. [in Ukraine].

Постановка задачі. Знімання стружки під час шліфування здійснюється дискретним рельєфом різальної поверхні круга (РПК) з різновисотними вершинами абразивних зерен після правки. Важливу інформацію про різальну здатність абразивного інструмента дають геометричні параметри рельєфу РПК.

Після правки РПК параметри характеристики абразивних кругів (зернистість, твердість, структура) видозмінюються на параметри геометрії рельєфу різальної поверхні, основними з яких за аналогією 3 визначенням шорсткості обробленої поверхні є відносна опорна довжина і середній крок нерівностей по вершинах.

Основоположниками профілографування РПК методом ощупування рельєфу алмазною голкою були С.О. Попов і М.П. Малєвський $[1 ; 2]$.

Удосконалена конструкція установки (рельєфографа) з урахуванням досвіду [24] дослідження рельєфу РПК приведена в роботі [5] на базі плоскошліфувального верстата (рис. 1).

Суттєвою особливістю розробки є спроможність відстежуючої системи вести профілографування алмазною голкою прямолінійно по одній і тій же трасі (після правки і після шліфування).
На рис. 2 наведено приклад запису профіля РПК 3 позначенням його основних параметрів.

Під час обробки профілограм (рис. 2) визначалися відносна опорна довжина

$$
t_{p}=\frac{\sum_{i=1}^{n} b_{p i}}{L}
$$

і відстань між сусідніми виступами

$$
l_{p}=\frac{L}{z_{p}}
$$

профіля на фіксованому рівні $p\left(\sum_{i=1}^{n} b_{p i}\right.$ сумарна довжина відрізків виступів, $z_{p}$ число виступів-зерен).

Середня ширина профіля зерен

$$
b_{p}=t_{p} l_{p}
$$

і середнє число зерен на одиницю $l$ довжини

$$
z_{p}=\frac{1}{l_{p}}
$$

витікають із параметрів (1) і (2).

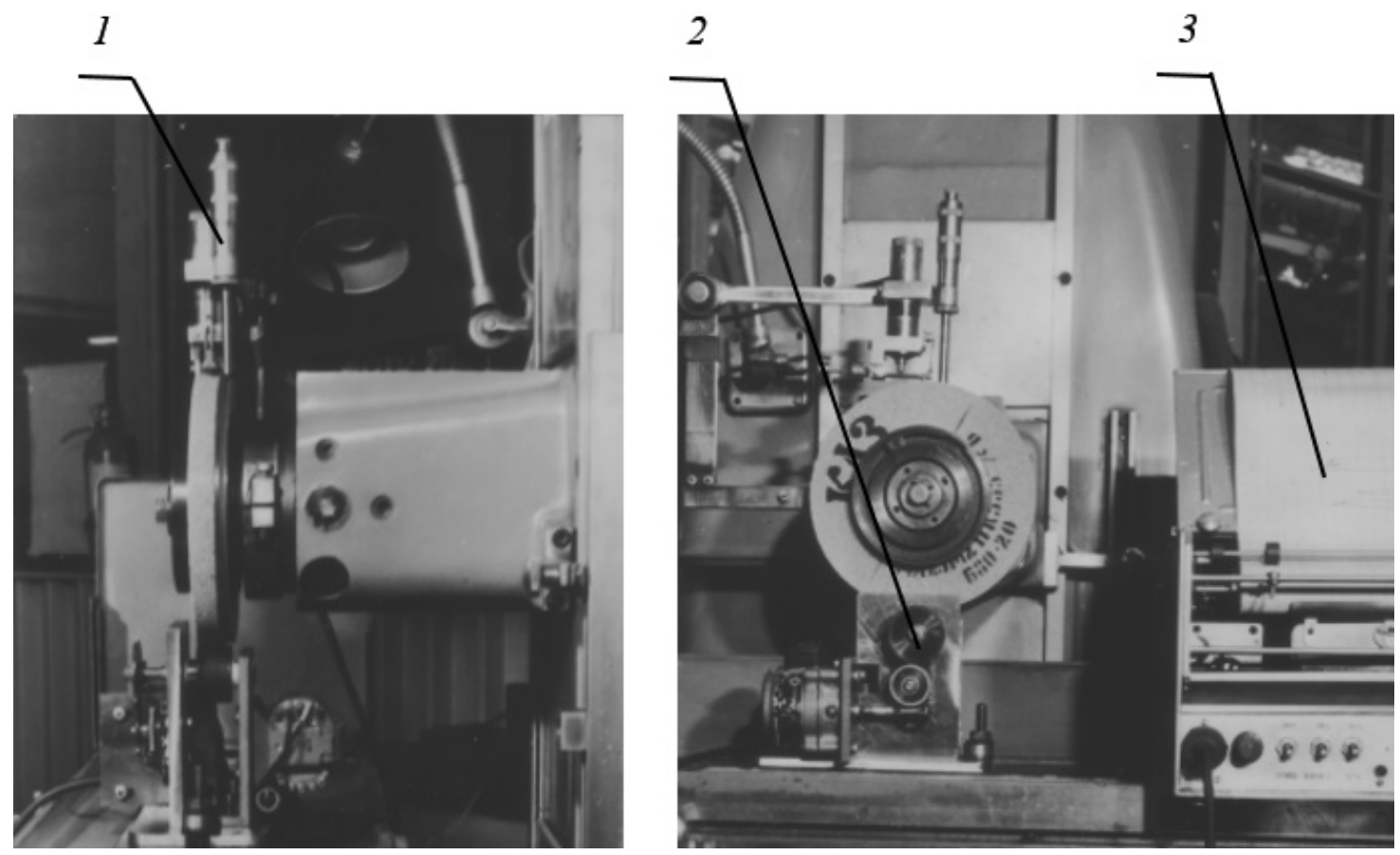

Рис. 1. Загальний вигляд установки у двох проєкціях: 1 - устрій ощупування рельєфу, 2 - привід обертання круга, 3 - стрічковий самописець 


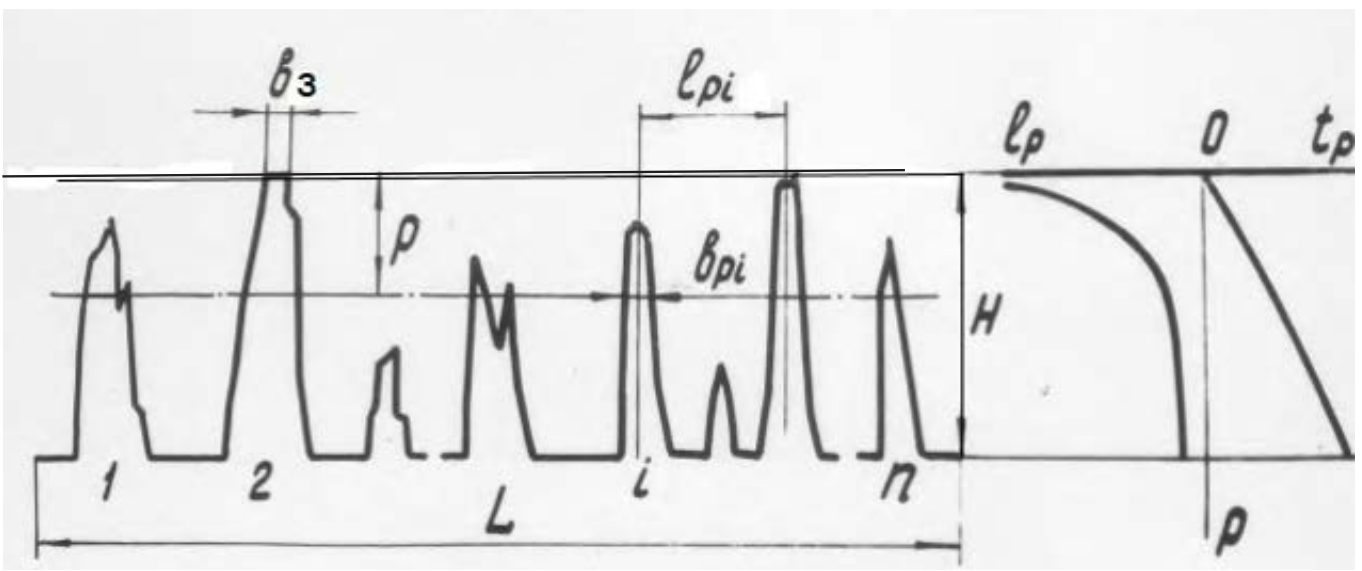

Рис. 2. Основні елементи профіля абразивної поверхні: $L$ базова довжина профілограми, $H$ глибина запису профіля, $p$ рівень перетину профіля, $1,2 \ldots i \ldots n$ виступи профіля над рівнем $\mathrm{p}, l_{p i}$ відстань між виступами, $b_{p i}$ ширина виступу, $b_{3}^{\sim}$ ширина затупленої площадки виступу на верхньому рівні $p$

Аналіз останніх досліджень і публікацій. Прикладні та методичні аспекти управління процесом шліфування розглянуті в численних сучасних роботах. Так, у роботі [6] на основі відносної опорної довжини $t_{p}$ і відстані між виступами $l_{p}$ профіля РПК був покладений початок аналітичним розрахункам товщини зрізу металу на одиничне зерно i сил різання на передній і задній поверхнях зерен. Для обгрунтування ефективних умов шліфування розроблена оптимізаційна модель у вигляді системи залежностей енергетичних, стійкісних і якісних показників процесу від параметрів характеристики абразивних кругів, які дали змогу визначити оптимальні зернистість, твердість і структуру абразивного інструмента за певних технічних обмежень показників конкретної операції.

Формуванню РПК за рахунок правки шліфувальних кругів із застосуванням ультразвукових коливань присвячені роботи $[7 ; 8]$, де встановлено зв'язок між геометричною формою робочої поверхні алмаза, глибиною правки і параметрами коливань правлячого інструмента. Більш розвинутий рельєф дає значне збільшення продуктивності шліфування і періоду стійкості кругів. Робота [9] стосується розробки абразивного інструмента 3 підвищеною структурністю для високопродуктивного шліфування.

Відокремлення не вирішених раніше частин загальної проблеми. Невирішеними питаннями загальної проблеми прогнозування різальних властивостей та обгрунтованого вибору характеристик абразивних кругів залишаються відсутність залежностей параметрів абразивного рельєфу від характеристики абразивного круга.

Мета дослідження - встановити залежність відносної опорної довжини $t_{p}$ і середньої відстані між зернами $l_{p}$ від параметрів характеристики абразивного круга. Необхідними параметрами геометрії рельєфу РПК для прогнозування різальних влас- тивостей і обгрунтованого вибору характеристики абразивних кругів, а також розрахунку геометрії зрізу одиничним зерном є параметри (1-4).

Методи, об'єкт та предмет дослідження. Об'єктом дослідження є процес формування різальної поверхні абразивного інструмента, а предметом дослідження геометричні параметри вказаної поверхні.

Для досягнення поставленої мети були проведені три серії однофакторних досліджень рельєфу РПК. Параметри характеристики абразивних кругів та режими їх правлення наведені в табл. 1.

Режими технологічного процесу обробки виробів правленими шліфувальними кругами наведені в табл. 2.

Таблиця 1. Параметри характеристики абразивних кругів та режими їх правки

\begin{tabular}{|c|c|}
\hline Параметри чи режими & Діапазон значень \\
\hline Абразивний матеріал & Білий електрокорунд \\
\hline марки 24А & $80,60,46$ \\
\hline Зернистість & $H, J, L$ \\
\hline Твердість & $5,8,11$ \\
\hline Номер структури, $N$ & $V$ \\
\hline Керамічна зв'язка & $\leq 0,1$ \\
\hline $\begin{array}{c}\text { Площадка зносу алмаза } \\
\text { в оправі, мм }\end{array}$ & 35 \\
\hline Швидкість круга $V, \mu / c$ \\
\hline $\begin{array}{c}\text { Поперечна подача під час } \\
\text { правки } S_{n}, \text { мм/об }\end{array}$ & 0,1 \\
\hline $\begin{array}{c}\text { Глибина правки } t_{n}, \\
\text { мм/подвійний хід }\end{array}$ & 0,01 \\
\hline
\end{tabular}

Джерелом інформації для визначення $t_{p}(1) \mathrm{i} l_{p}$ (2) служили записи профілограм на паперовій стрічці шириною 200 мм і довжиною 1-2 м (залежно від зернистості) зі збільшенням $\times 2000$ по вертикалі і $\times 40$ по горизонталі. Приклад профілограми для параметрів характеристики «нульового» рівня (зернистість 60, твердість $J$, структура 8) наведено на рис 3. 
Таблиця 2. Технологічні режими шліфування виробів

\begin{tabular}{|c|c|}
\hline Режими & Діапазон значень \\
\hline $\begin{array}{c}\text { Марка оброблюваного } \\
\text { матеріалу }\end{array}$ & $\begin{array}{c}\text { Швидкорізальна сталь } \\
\text { М2 (Р6М5) }\end{array}$ \\
\hline Вид обробки & $\begin{array}{c}\text { Сухе площинне } \\
\text { шліфування }\end{array}$ \\
\hline $\begin{array}{c}\text { Час контакту круга } \\
\text { із заготовкою, хв }\end{array}$ & 0,2 \\
\hline Твердість сталі & $H R C э 62 \ldots 64$ \\
\hline Швидкість круга $V, \mu / c$ & 35 \\
\hline Поздовжня подача $s, \mathrm{~m} / \mathrm{xв}$ & 10 \\
\hline $\begin{array}{c}\text { Глибина шліфування } t, \\
\text { мм/подвійний хід }\end{array}$ & 0,02 \\
\hline
\end{tabular}

Огляд профілограми дає візуальне уявлення щодо розташування виступів по довжині траси та їх різновисотність по глибині залягання. Після шліфування рідшає їх розташування, а висота помітно знижується.

Для визначення закономірностей зміни параметрів $t_{p}$ i $l_{p}$ рельєфу РПК після правки від зернистості, твердості і структури абразивних кругів було одержано й оброблено більше 30 профілограм (архів профілограм та фотографій зберігається).

Основний матеріал. Початковими даними прийняті такі положення. Зовнішній рельєф РПК під час правки формується по глибині на зернах внутрішнього перетину абразивного об'єму (матриці). На основі рівності співвідношень відносних опорних об'єму $t_{V}$ , площі $t_{s}$, довжини $t_{l}$ і об’ємної концентрації зерен $n_{z}[10 ; 11]$ параметри абразивної матриці розраховуються за встановленими $[12 ; 13]$ залежностями:

середній діаметр (математичне очікування) еліпсоїдного зерна $d_{z}=1,105 d$ (d - номінальний розмір зернистості, $\mathrm{d}=0,25$ мм відповідає номеру зернистості 60);

об'єм одного зерна $w_{z}=\frac{-}{6} d_{z}^{3}$;

об'ємна концентрація зерен $n_{z}=\frac{62-2 N}{100}$ (N - номер структури характеристики шліфувального круга);

величина хорди перетину зерен

$$
b_{x}=\sqrt{\frac{2}{3}} \frac{1}{4} d_{z}
$$

кількість зерен на одиниці довжини

$$
z_{l}=\sqrt{\frac{2}{3}} \frac{6 n_{z}}{d_{z}}
$$

кількість зерен на одиниці площі

$$
z_{S}=\frac{6 n_{z}}{d_{z}^{2}}
$$

Фактично кількість зерен на РПК дорівнює тільки тій частині $z_{l}(6)$ і $z_{S}(7)$, яка розподілена на рівні граничної глибини впливу процесу правки.

Прийом штучного роз'єднання абразивного об'єму висотою $d_{z}$ на дві асиметричні частини дає змогу одержати вихідний рельєф РПК на основі параметрів $z_{l}(6)$ і $z_{S}(7)$ абразивної матриці, з якої він безперервно утворюється.

У роботі [13] аналітико-ймовірнісним методом одержані розрахункові формули для відносної опорної довжини

$$
t_{l}=n_{z},
$$

ширини хорд (перетинів)

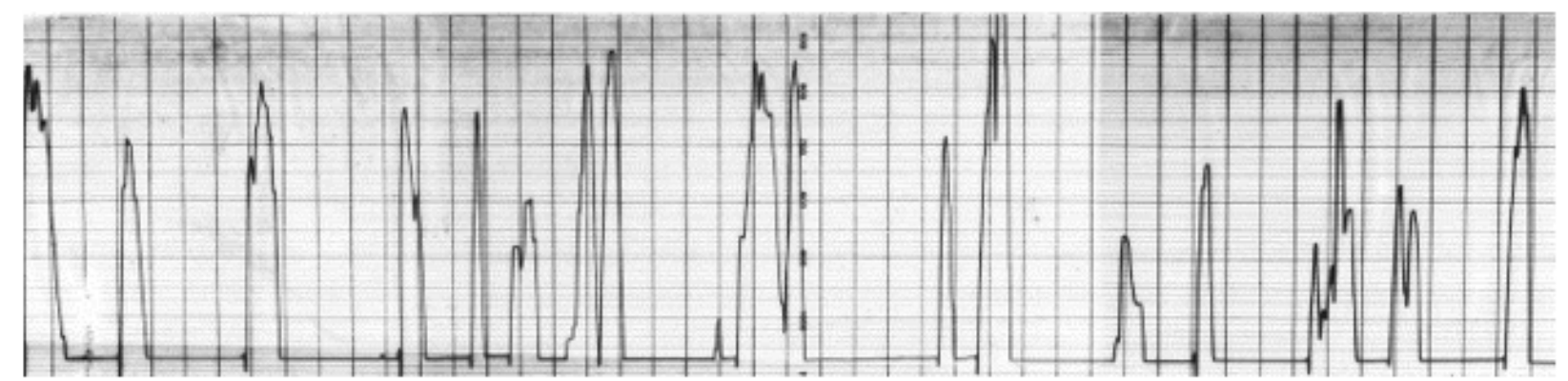

a)

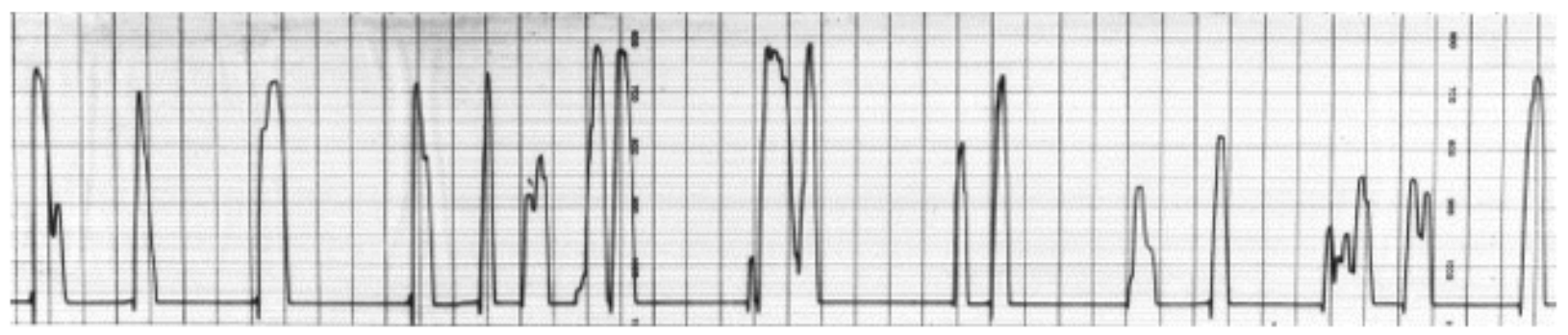

б)

Рис. 3. Фрагменти профілограми РПК для характеристики круга $24 A 60 \mathrm{~J} 8 \mathrm{~V}$ : a - після правки, б - після шліфування 


$$
b_{x}=\sqrt{\frac{2}{3}} \frac{1}{4} d_{z} \sqrt{q},
$$

кількості зерен (хорд) на одиниці довжини

$$
z_{l}=\sqrt{\frac{2}{3}} \frac{6 n_{z}}{d_{z}} \frac{}{\sqrt{q}}
$$

і кількість зерен (кругів) на одиниці площі

$$
z_{S}=\frac{6 n_{z}}{d_{z}{ }^{2}} \frac{9}{q}
$$

рельєфу РПК, де $=\frac{p}{d_{z}}-$ відносна глибина (рівень) профіля;

$q=1-e+6+0,46^{2} 37,73^{3}+69,92,73^{4}-35,94^{5},<0,5-$

функція розподілу приведеного (еквівалентного) профіля зерна по глибині.

На рівні $=0,5$ маємо такі параметри абразивної матриці $t_{l}=0,5 n_{z}, q=1, b_{x}=b_{x}$ (5), $z_{l}=0,5 z_{l}$ (6), $z_{S}=0,5 z_{S}(7)$.

Обговорення отриманих результатів. Вплив зернистості круга $d_{z}$ описано графіками на рис. 4 .

Графіки показують однозначну закономірність: по мірі збільшення $d_{z}$ відбувається зменшення $t_{p} \mathrm{i}$ збільшення $l_{p}$.

Вилив твердості $h$ ( $h$ - глибина лунки вимірювання у разі застосування піскоструминного методу за тиску повітря 0,05 МПа та порції піску в камері об'ємом 28 см ${ }^{3}$ згідно $з$ відповідним стандартом).

Твердість абразивного інструмента регулюється вмістом зв'язки і найбільшою мірою впливає на параметри рельєфу.

Природно, що в процесі правки в більш твердих кругах формується менш шорсткий рельєф. Наглядний доказ цього дають графіки (рис. 5) зміни $t_{p}$ i $l_{p}$ від глибини рельєфу р для трьох ступенів твердості (по граничній $h$ за тиску повітря 0,05 МПа).

Шліфувальні круги твердістю $H$ мають найменше значення $t_{p}$ і найбільше $l_{p}$, а твердістю $L-$ навпаки.

Вилив структури $n_{z}$. Структура абразивного інструмента характеризує об'ємний вміст зерен. На рис. 6 представлені графіки експериментальних даних по параметрах геометрії рельєфу РПК для структур з номерами 5, 8, 11 (сфера технологічних можливостей виготовлення інструмента на керамічних зв'язках).

Збільшення номера структури і непряме збільшення пористості абразивних кругів призводить до суттєвого зменшення $t_{p}$ i росту $l_{p}$.

Вилив процесу шліфування. Зіставленням профілограм по одній трасі після правки і після шліфування установлено три види зміни геометрії рельєфу РПК: викрошення, мікроруйнування (сколи і надломи) і затуплення (утворення площадок зносу) зерен.

Викрошення зерен більш характерне для м'яких абразивних кругів. Так, для абразивних кругів твердості $L$ кількість викрошених окремих зерен за профілограмами становило 5-7\%, а для твердості

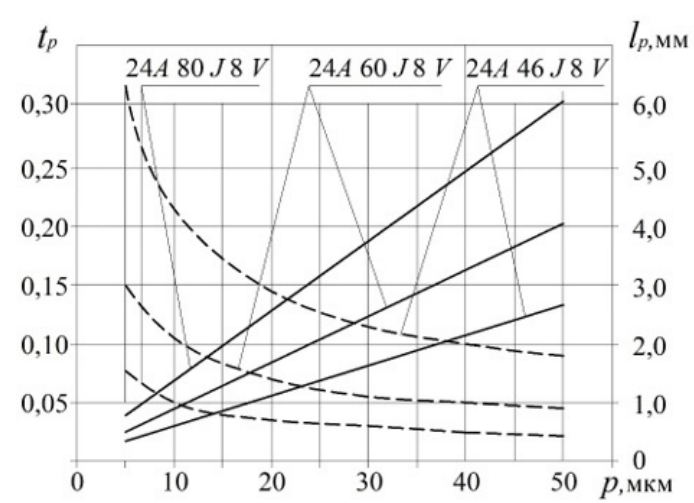

Рис. 4. Зміна опорної довжини $t_{p}$ (безперервні лінії) $\mathrm{i}$ відстані $l_{p}$ (штрихові лініі) від глибини $p$ рельєфу РПК за різних характеристик абразивного круга стосовно зернистості 80, 60, 46

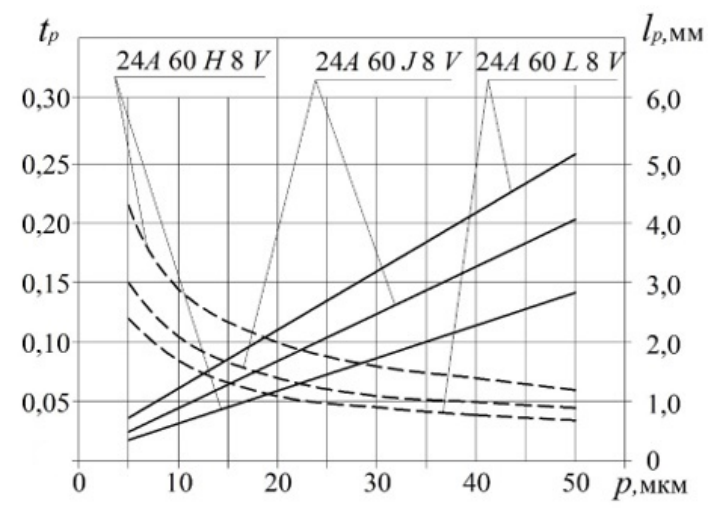

Рис. 5. Зміна опорної довжини $t_{p}$ (безперервні лініі) $\mathrm{i}$ відстані $l_{p}$ (штрихові лінії) від глибини $p$ рельєфу РПК за різних характеристик абразивного круга стосовно твердості $H, J, L$

$H-20-25 \%$. Для крупнозернистих твердих абразивних кругів це явище взагалі є рідкісним.

В основному зношення абразивних кругів відбувається за рахунок механічного стирання досить міцних і надійно утримуваних зв'язкою зерен, а також частково за рахунок сколювання і надлому крихких зерен неправильної форми. Загальна кількість затуплених зерен становить близько $30 \%$, а середня ширина площадки зносу профіля зерен досягає 0,03-0,05 мм для абразивних кругів зернистості 60 , що і $€$ головною причиною обмеження їх періоду стійкості під час шліфування зносостійких швидкорізальних сталей.

Для більш твердих кругів характерне деяке збільшення опорної довжини $t_{p}$, а середня відстань між зернами $l_{p}$ залишається майже без змін. Більш м'яким кругам, які працюють у режимі часткового самозаточування, притаманне деяке збільшення відстані між зернами $l_{p}$ за майже незмінної опорної довжини $t_{p}$.

Реалізація. Апроксимація експериментальних залежностей рис. $\tilde{4} 6$ у логарифмічній системі координат $t_{p}, l_{p}-\varepsilon$ методами визначення показника ступеня 


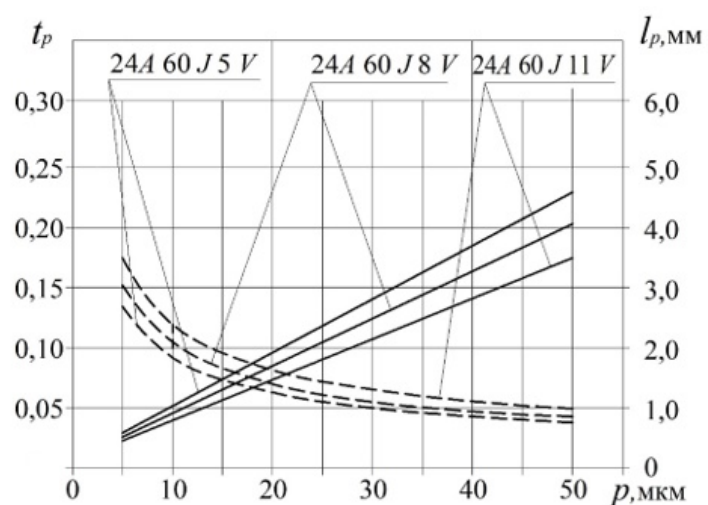

Рис. 6. Зміна опорної довжини $t_{p}$ (безперервні лінії) $\mathrm{i}$ відстані $l_{p}$ (штрихові лініі) від глибини $p$ рельєфу РПК за різних характеристик абразивного круга стосовно структури $5,8,11$

при $\varepsilon$ і підбору поправочного коефіцієнта на твердість $h$ дала змогу одержати розрахункові формули розподілу відносної опорної довжини $t_{p}$ i відстані між профілями зерен $l_{p}$

$$
\left\{\begin{array}{l}
t_{p}=\varepsilon^{v} \cdot C_{t} \cdot n_{z} \\
l_{p}=\varepsilon^{-\lambda} \cdot C_{l} \cdot l_{z}
\end{array}\right.
$$

на основі значень концентрації зерен

$$
n_{z}=\frac{62-2 N}{100}
$$

( $N$ - номер структури) і відстані між зернами

$$
l_{z}=z_{l}^{-1}=0,641 \frac{d_{z}}{n_{z}}
$$

( $d_{z}$ - розмір абразивного зерна) (6).

Для таких умов правки електрокорундових кругів алмазом в оправі (табл. 1) визначені показники ступеня за відносної глибини профіля $=\frac{p}{d}$ ( $p$ - значення глибини від нульового рівня): $=0,89$ $\mathrm{i}=0,55$. Також визначені значення коефіцієнтів $C_{t} \mathrm{i}$ $C_{l}$, які враховують вплив твердості абразивних кругів (табл. 3).

Вплив процесу правки за умов $t_{p}, l_{p}$ (13) визначено (рис. 7) на прикладі порівняння графіків розподілу ширини (хорди) профіля приведеного зерна по відносній глибині. Також на основі експериментальних даних та аналітичного розрахунку визначено кількість

\begin{tabular}{|c|c|c|c|c|c|}
\hline \multirow[t]{2}{*}{$\begin{array}{l}\text { Позначення } \\
\text { коефіцієнтів }\end{array}$} & \multicolumn{5}{|c|}{$\begin{array}{c}\text { Значення коефіцієнтів за твердістю } \\
\text { по ISO. У дужках наведені значення } \\
\text { глибини лунки } h, \text { мм }\end{array}$} \\
\hline & $H(6,2)$ & $I(5,3)$ & $J(4,4)$ & $K(3,6)$ & $L(2,9)$ \\
\hline$C_{t}$ & 1,41 & 1,72 & 2,02 & 2,29 & 2,56 \\
\hline$C_{l}$ & 1,22 & 1,01 & 0,87 & 0,76 & 0,70 \\
\hline
\end{tabular}
зерен (кругів) на одиниці площі (рис. 8) для рельєфу РПК з базовою характеристикою 24A $60 \mathrm{~J} 8 \mathrm{~V}$.

Таблиця 3. Значення коефіцієнтів $\boldsymbol{C}_{\boldsymbol{t}}$ і $\boldsymbol{C}_{\boldsymbol{t}}$
Площа перерізу (круга) приведеного зерна обчислюється через значення ширини (хорди) $b_{p}=t_{p} l_{p}=0,641^{-} C_{t} C_{l} d_{z}(13)$ і діаметра

$d_{\kappa}=\frac{4}{-} b_{\kappa}[12]$ за формулою

$$
S_{z}=\frac{-}{4} d_{\kappa}^{2}=\frac{-}{4}\left(0,816^{-} C_{t} C_{l} d_{z}\right)^{2} .
$$

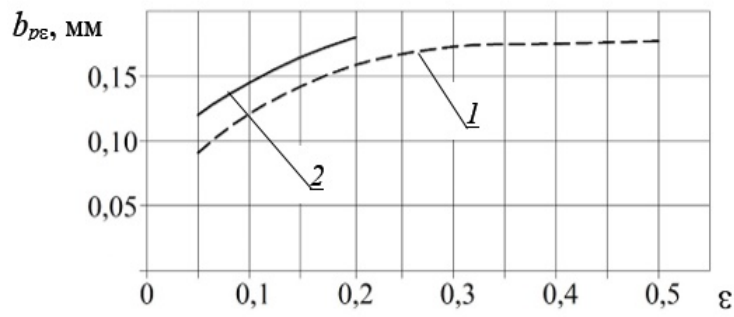

Рис. 7. Розподіл ширини профіля приведеного зерна рельєфу РПК характеристики шліфувального круга $24 A 60 \mathrm{~J} 8 \mathrm{~V}$ по відносній глибині профіля $\varepsilon: 1$ аналітичний розрахунок $b_{\kappa}(9) ; 2$ - емпірична залежність $b_{p}=t_{p} l_{p},(13)$

Тоді кількість зерен рельєфа РПК на одиниці площі визначається із відношення опорної площі $t_{S}=C_{t} n_{z}$ (13) до площі перерізу зерна $S_{z}(14)$ і дорівнює:

$$
z_{S}=\frac{t_{S}}{S_{z}}=\frac{1.912 n_{z}}{{ }^{-2} C_{t} C_{l}^{2} d_{z}^{2}}
$$

Внаслідок правки (відповідно до розрахунку аналітико-ймовірнісної моделі) одержуємо менш гострий профіль приведеного зерна і менш дискретний рельєф РПК.

Виявлені основні закономірності формування i описання рельєфу РПК методами математичної статистики дають змогу надалі перейти до розрахунку числа активних зерен у контакті шліфувального круга-заготовки, товщини зрізу окремим зерном і складників сили різання під час шліфування.

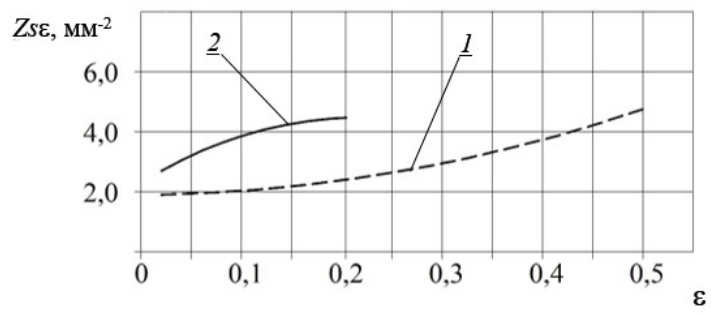

Рис. 8. Розподіл кількості зерен на одиниці площі по відносній глибині профіля $\varepsilon: 1$ - аналітичний розрахунок $\mathrm{Z}_{s}$ (11); 2 - емпірична залежність $\mathrm{Z}_{s}(15)$

\section{ВИСНОВКИ}

1. Створена установка для профілографування рельєфу РПК зі спеціальним устроєм ощупування 
абразивних зерен забезпечує достатню точність вимірювання профіля зерен і відтворення результатів профілографування після правки і після шліфування по одній трасі.

2. Проведено аналіз впливу параметрів характеристики електрокорундових абразивних кругів на керамічній зв'язці (зернистості, твердості, структури) на відносну опорну довжину профіля $t_{p}$ i середню відстань між зернами по глибині рельєфу р після правки РПК.

3. На основі значень об'ємної концентрації зерен і відстані між зернами на абразивній матриці встановлені комплексні емпіричні залежності у вигляді розрахункових формул опорної довжини $t_{p \varepsilon} \mathrm{i}$ відстані між зернами по відносній глибині рельєфу $\varepsilon$ від зернистості, твердості і структури кругів.
4. Головним фактором обмеження періоду стійкості (часової наробки) електрокорундових абразивних кругів під час сухого шліфування загартованих швидкорізальних сталей за критерієм «припал» шліфованої поверхні є затуплення вершин зерен на нульовому рівні рельєфу з утворенням для зернистості 80 - 46 (ISO 8486) площадок зносу профілю зерен 0,03-0,05 мм залежно від умов шліфування.

5. Порівняно з параметрами рельєфу різальної поверхні круга, які визначені аналітико-ймовірнісним методом, процес правки алмазом в оправі створює менш розвинутий дискретний рельєф 3 меншим загострюванням профілю приведеного зерна і більшою кількістю вершин зерен на одиницю площі, що поряд $з$ нівелюванням рельєфу РПК сприяє стабілізації різальної здатності абразивних кругів.

\section{Список літератури}

[1] Попов С.А., Малевский Н.П. Новый метод оценки режущих свойств абразивных инструментов. Москва : ВИНИТИ. $1959.157 \mathrm{c}$.

[2] Попов С.А., Малевский Н.П., Терещенко Л.М. Алмазно-абразивная обработка металлов и твердых сплавов. Москва : Машиностроение. 1977. 263 с.

[3] Попов С.А., Малевский Н.П., Булошников В.С. Устройство для профилографирования рельефа режущей поверхности шлифовальных кругов на станке 3А151. Сборник «Обработка материалов резанием», Москва : Изд-во ВЗМИ, 1976. с. $154-161$.

[4] Малевский Н.П., Булошников В.С., Попов С.А. Стенды и приборы для исследования процессов алмазноабразивной обработки материалов. Сборник «Резание и инструмент». Труды МВТУ № 324. 1980. Москва : Изд-во МВТУ, с. 80-134.

[5] Попов С.А., Кравченко Ю.Г., Жученко А.В. Профилографирование рельефа режущей поверхности шлифовальных кругов. Сб. «Резание и инструмент», вып. 27. Харьков : Вища школа. 1982, с. 10-14.

[6] Кравченко Ю.Г. Исследование процесса высокопроизводительного шлифования сложнолегированных быстрорежущих сталей кругами на керамической связке : дисс. канд. техн. наук : 05.03.01. Москва : МВТУ им. Баумана. 1980. 231 с.

[7] Мурашкин С.В. Повышение эффективности процесса шлифования за счет правки шлифовальных кругов с применением ультразвуковых колебаний : автореферат дисс. канд. техн. наук : 05.03.01. Ульяновск : УлГТУ, 2006.18 с. URL: http://www.ulstu.ru/main?cmd=file\&object=730.

[8] Малышев В.И., Мурашкин С.В., Комлев Р.В. Формирование рабочей поверхности шлифовального круга при ультразвуковой правке. «Вектор науки ТГУ», № 2(12). Тольятти : ТГУ, 2010. С. 40-43.

URL: http://edu.tltsu.ru/sites/sites_content/site1238/html/media63159/07-Malyshev.pdf.

[9] Рябцев С.А. Разработка абразивного инструмента с повышенной структурностью и управляемой пористостью для высокопроизводительного шлифования фасонных поверхностей деталей из труднообрабатываемых материалов : дисс. докт. техн. наук: 05.02.07. Московский государственный технологический университет «СТАНКИН». Москва : «Станкин», 2011.387 c. URL: https://www.dissercat.com/content/razrabotka-abrazivnogo-instrumenta-s-povyshennoi-strukturnostyu-i-upravlyaemoi-poristostyu-d.

[10] Салтыков С.А. Стереометрическая металлография. Москва : Металлургия. 1970. 375 с.

[11] Чернявский К.С. Стереология в металловедении. Москва : Металлургия. 1977. 280 с.

[12] Кравченко Ю.Г. Параметрирование абразивной матрицы шлифовальных кругов. Сб. «Резание и инструмент в технологических системах», вып. 57. Харьков : ХГПУ, 2000. С. 126-130.

[13] Кравченко Ю.Г. Строение исходного рельефа режущей поверхности шлифовальных кругов. Збірник наукових праць «Високі технологї̈ в машинобудуванні», вип. 1(3). Харків : ХДПУ, 2000. с. 154-160.

(C) Ю. Г. Кравченко, С. Т. Пацера 